Zachorowska-Mazurkiewicz, A., \& Sierotowicz, T. (2017). Women, men and creativity in higher education sector - comparative studies of leading EU and ECE countries. Journal of International Studies, 10(3), 105-119. doi:10.14254/2071-

\title{
Women, men and creativity in higher education sector - comparative studies of leading EU and ECE countries
}

\author{
Anna Zachorowska-Mazurkiewicz \\ Faculty of Management and Social Communication, \\ Jagiellonian University \\ Poland \\ Email: anna.zachorowska@uj.edu.pl \\ Tomasz Sierotowicz \\ Faculty of Management and Social Communication, \\ Jagiellonian University \\ Poland \\ Email: tsierotowicz@uj.edu.pl
}

Abstract. The focus in the article is on creativity in the higher education sector in terms of gender perspective. The question posed concerns the relation between women's and men's patent activities and R\&D expenditures. The paper is based on the data from the European Patent Office, 1999-2013 concerning creative activities performed by women and men in the higher education sector. The paper looks into the dynamics of changes in terms of the number of women and men researchers, $\mathrm{R} \& \mathrm{D}$ personnel and inventors, and combines them with the changes in R\&D expenditures in the higher education sector. The analysis is conducted for the two groups of leading EU countries in the light of their patent activities.

Received: May, 2017

1st Revision:

July, 2017

Accepted:

October, 2017 The objective of this exercise is to present the correlation between R\&D expenditures and women and men in the R\&D sectors, comparing these two groups of the EU countries.

Keywords: R\&D, creativity, patent, gender, innovation management.

JEL Classification: O31, O32, O34, O39, O57

\section{INTRODUCTION}

The main focus of the article is on innovativeness and creativity in the higher education sector considered in the gender perspective. It also concerns the relation between patent activities of women and men employed in higher education on the one hand and R\&D expenditures on the other. The paper is based on the data obtained from the European Patent Office (EPO) for the years 1999-2013 concerning the creative activities by women and men employed in this sector. The sense and possibilities of using patent datasets in scientific research were introduced by the following researchers: Cohen, Nelson, \& Walsh (2002, 
2003); Griliches (1990), Pavitt (1989); Guellec, Pottelsberghe, (2000, 2001, 2007); Jaffe, Trajtenberg, \& Henderson, (1993); Schmoch $(1997,2008)$. These authors point at the information gathered in patent statistics as one of the components of the system measuring technological change, scientific and innovative activity as well as general structural changes in the economic environment. Patent statistics, an important source of information about the current level of economies' development, is still insufficiently applied, primarily because of the limitations in the methods of using patent statistics, which are far from the holistic approach.

The paper looks into the dynamics of changes in terms of the number of women and men researchers, $R \& D$ personnel and inventors employed in higher education sector, and combines them with the changes in $R \& D$ expenditures in this particular sector. The exercise is based on the disaggregation of data by gender. The objective of this exercise is to present the correlation between $R \& D$ expenditures and employment of women and men in the R\&D sector, so that to compare the two distinguished groups of countries. The analysis is conducted for the EU countries. The paper begins with distinguishing two groups of countries in terms of patent activity in the European Union: 10 leading EU economies and three leading transition countries that are currently members of the European Union.

In the following section of the article the number of women and men researchers and other R\&D personnel are analysed in two groups, then the analysis of the numbers of women and men innovators follows. Methods used in the presented research allowed defining and comparing the dynamics of changes in expenditures on research and development in higher education with the dynamics of changes in employment of women and men as R\&D personnel and researchers, as well as with the women's and men's creativity expressed through the number of inventors of industrial property in this sector.

The undertaken research allowed defining the specificity of the observed changes which made it possible to answer the main research question: is (and to what extent) an increase in expenditures on R\&D in higher education sector promoting the employment of women and men as R\&D personnel and researchers, and an increase in women's and men' creativity expressed in the number of industrial property inventors?

\section{LITERATURE REVIEW}

Science and society are highly interdependent, each affecting the other, and technological innovation, like scientific research, are not gender-neutral activities. The gender dimension is deeply embedded in the way we do science and develop new technologies, influencing the entire process of technological innovation Abels (2012, p. 187). However, the European Commission (2001, p. 12) notices that the perception of technology and science is gender-blind, science through its search for objectivity tends to dismiss gender dimension. The study presented in the paper is a step towards inclusion of gender dimension into considerations regarding innovations, through looking at gender structure of innovators.

Research project presented in the article focuses on gender and innovation, and it is worth starting with the definitions of the main concepts. Innovations are defined in the classic definition by Schumpeter (1934) as new combinations of production factors such as the production of new goods, introduction of new processes, opening of new markets, access to new sources of raw materials and intermediates, and reorganization of an industry. Therefore, innovations range from product, service, process, position, strategic, governance or rhetorical propositions, and as to whether they are revolutionary, radical, emergent or incremental (Fogelberg Eriksson, 2014, p. 165).

Gender has not been a frequent focus of innovation-based research (Carrasco, 2014, p. 411). The concept of gender and innovation has only recently gained a wider interest among researchers. One of the 
reasons for this lack of gender is the apparent invisibility of people in innovation (Alsos, Ljunggren, \& Hytti, 2013, p. 237). Alsos et al. (2013) notice that when people are not visible in the discourse, gender easily becomes invisible. Thus, it is challenging to reveal the impact of gender on innovation when it is hidden within processes, organizations and systems. Alsos et al. (2013, p. 239-240) conducted studies searching for articles in scientific journals from the Scopus database devoted to innovation and gender. While they were able to find 106994 articles that included the word "innovation" in the title, abstract or as a keyword, when they have combined the word "innovation" with the word "gender" the number of articles fitting the criteria decreased to 615, with no journal containing more than four articles of such focus. The number of articles combining words "innovation" and "women" was 1 306. This is however not the whole story, since a high proportion of these articles focusing on gender and innovation are within medicine, nursing, psychology or technology/engineering. They have continued with the examination of economic literature. They have found out that within economics the most prominent studies are those based on science and innovation areas, using quantitative methods including surveys and/or register data.

A number of studies and reports that deal with the issues of innovation and gender have stressed the acute problem of women's underrepresentation in science in the business sector (OECD, 2012; Hunt, Herman, \& Munroe, 2013; Zachorowska-Mazurkiewicz, \& Sierotowicz, 2016). The results of international empirical comparative studies indicate that, in general, there is a clear statistical pattern that women are less involved than men in the creation of scientific and industrial knowledge, (Larivière, Gingras, Cronin \& Sugimoto, 2013; Whittington \& Smith-Doerr, 2005; Frietsch, Haller, Funken-Vrohlings, \& Grupp, 2009), with the largest proportion of female inventors in the EU observed in Denmark (11.85\%), Finland (8.57\%), Sweden (7.79\%) and Germany (5.24\%) (Okoń-Horodyńska, Zachorowska-Mazurkiewicz, Sierotowicz, \& Wisła, 2015). The research so far concentrated on simple relations between gender and the number of inventions, mostly in the industrial sector, indicating that there is a gender gap, leaving however the question regarding the significance of this gap for the creativity, open.

Hence, it is worth asking the question, whether gender diversity is important for the creativity and innovations. Østergaard et al. (2011) claims that the likelihood of introducing an innovation is greater in organizations in which minority group has a critical mass to contribute to the innovation process, in a maledominated organization, gender has a moderating effect on the relationship between idea generation and implementation, because women employees will face more hurdles (Foss et al., 2013, p. 301). Research shows that creative performance requires both masculine and feminine components (Jönsson, \& Carlsson, 2000, cited by Foss et al., 2013, p. 304). Østergaard et al. (2011) study shows a strong positive and significant relation between gender diversity and innovation. The results of that study show that very low or very high levels of diversity are not significantly different from each other, nevertheless a moderate degree of diversity (where a minority group has a critical mass to contribute to the innovation process), appears to have a higher likelihood of introducing an innovation.

Patent statistic was used previously to research problems regarding creativity and innovativeness, but selectively in the industrial sector and without gender related issues Griliches (1990), Hirschey \& Richardson (2004). Previous study conducted by Zachorowska-Mazurkiewicz and Tomasz Sierotowicz (2016) focused on gender structure, but similarly only in the business sector, and it showed that in all EU leading countries the number of women inventors of industrial property in business sector was increasing in the whole period under study. In the majority of the countries, the number of women researchers and R\&D personnel increased more rapidly than the number of men, and in all the countries the increase in the number of women inventors was higher than men, the success in terms of the number of patents awarded is the outcome of the changes in the structure by gender. The study conducted in the group of leading transition countries show that the dynamics of growth in the number of men inventors of industrial property is higher 
than in the case of women inventors in the same period under study. It is a different situation than in the EU leading countries, where the number of women inventors of industrial property was increasing at the higher pace than the number of men. It could be concluded that the role of women in the process of innovation is limited in business sector in transition countries. This limitation leads to the decreasing role of women inventors of industrial property in business sector. That could also be a factor explaining poor performance of these countries in terms of patent obtained. In the current paper, the similar methodology has been used, however, this time the focus the higher education sector.

\section{METHODOLOGY}

The article uses the full patent database (for European Patent Office - EPO) of Thomson Innovation developed by Thomson Reuters for the period of 1999-2013. Work with such an extensive metadata set of bibliographical descriptions requires the application of automated techniques of grouping items using dictionaries of female and male names, as well as typology of other agents (separately for inventors and entities applying for a patent) and postal codes (indicated separately as a standard as part of the addresses of patent inventors and seats/addresses of entities applying for a patent). Thus, presented results are not a simple presentation of patent statistics that could be found in EPO database. The research period - $1999-$ 2013 - was chosen, on one hand due to the integrity of primary data obtained from EPO database, and on the other hand because such a long time series allows to use statistical tools that enable assessment of dynamic changes in women's and men's creativity. From patent statistics the data chosen concern time series of annual numbers of female and male inventors of novelties that received patent protection in years 19992013 under European patent application including their association with agents belonging to higher education sector. Additionally, Eurostat data have been used regarding indicators, such as: "Total R\&D personnel and researchers of higher education sector", "Total intramural R\&D expenditure (GERD) of higher education sector". Comparison of time series presenting patent activities of women and men, who have been inventors in organizations defined as higher education sector with $\mathrm{R} \& \mathrm{D}$ expenditures in this particular sector allowed for conducting analysis and assessment of the dynamic changes in efficiency of such expenditures.

The research was carried out in three stages. The first one aimed to determine two groups of leading countries in terms of the number of women and men inventors from $19 \mathrm{EU}$ countries and from 9 transition states that are currently members of the EU: Bulgaria, Czech Republic, Estonia, Lithuania, Latvia, Poland, Romania, Slovakia and Hungary. At this stage of the research all EU countries were taken into consideration. The division into two separate groups was due to the fact that patent activity of 9 transition states measured by the number of patents awarded by the EPO in the whole period reached $0.78 \%$, while $99.22 \%$ was awarded to $19 \mathrm{EU}$ member states. Identified leading countries from the two groups were then used to obtain time series that are presented in table 1.

Table 1

Time series obtained during the preparation of entry data for all leading EU countries in the period 19992013

\begin{tabular}{|l|l|}
\hline \multicolumn{1}{|c|}{ Variables } & \multicolumn{1}{c|}{ Description } \\
\hline $\mathrm{rd}_{\mathrm{C}}$ & Time series of the total intramural R\&D expenditure (GERD) of higher education sector. \\
\hline $\mathrm{he}_{\mathrm{cwr}}$ & Time series of the women R\&D personnel and researchers in higher education sector. \\
\hline $\mathrm{he}_{\mathrm{cmr}}$ & Time series of the men R\&D personnel and researchers in higher education sector. \\
\hline $\mathrm{he}_{\mathrm{cwp}}$ & Time series of the women inventors of patents in the higher education sector. \\
\hline $\mathrm{he}_{\mathrm{cmp}}$ & Time series of the men inventors of patents in the higher education sector. \\
\hline
\end{tabular}

Source: authors' own work. 
In the second stage, using the time series for women and men being R\&D personnel and researchers of higher education sector (table 1), the research focused on the annual values of the ratio of the number of women to the number of men. In order to calculate the ratio, the following equation has been used:

$$
I w m_{a c r}=\frac{h e_{a c w}}{h e_{a c m}}
$$

where:

Iwmacr - annual value of women to men ratio for each country studied,

heacw - annual value of the time series, presented in table 1 , of variable representing women, he $e_{\mathrm{cwr}}$, he $\mathrm{cwp}_{\mathrm{cw}}$, respectively for each country covered by the research,

he acm - annual value of the time series, presented in table 1, of variable representing men, he $\mathrm{cmr}_{\mathrm{cm}}, \mathrm{he}_{\mathrm{cmp}}$, respectively for each country covered by the research,

$c-$ following country researched,

$a$ - following year in the time series,

$r$ - number of the following variable comprising time series, calculated as the women to men ratio.

Table 2

Time series of the annual values of the women to men ratio for each country examined in 1999-2013

\begin{tabular}{|l|l|}
\hline \multicolumn{1}{|c|}{ Variables } & \multicolumn{1}{|c|}{ Description } \\
\hline$I w m_{a c 1}$ & $\begin{array}{l}\text { Time series of the women to men ratio, being R\&D personnel and researchers of higher education } \\
\text { sector. }\end{array}$ \\
\hline$I w m_{a c 2}$ & Time series of the women to men ratio, being inventors of patents of the higher education sector. \\
\hline
\end{tabular}

Source: authors' own work.

The third stage of study was focused on dynamics of change, using time series of variables presented in tables 1 and 2. The dynamics of change was determined using the average rate of change in time, as demonstrated in the equations below (Freedman et.al. 2007, Sobczyk, 2007, Hughes-Hallett, et al., 2014):

$$
\begin{gathered}
\log \bar{y}_{C p}=\frac{1}{n-1} \sum_{i=2}^{N} \log \frac{y_{c p i}}{y_{c p i-1}} \\
A c_{C p}=\left(\bar{y}_{C p}-1\right) \times 100
\end{gathered}
$$

where:

$\bar{y}_{c p}$ - the geometric mean of chain indices calculated separately, specified variables (in tables 1 and 2) for each EU member state for the entire period under analysis,

$p$-following variable (in table 1 or 2 ), for which the calculation has been done in each country under analysis,

$N$ - number of observations in a time series (corresponding to the number of years of the period under analysis),

$i$ - following observation in the time series,

$c-$ next EU country included in the study, 


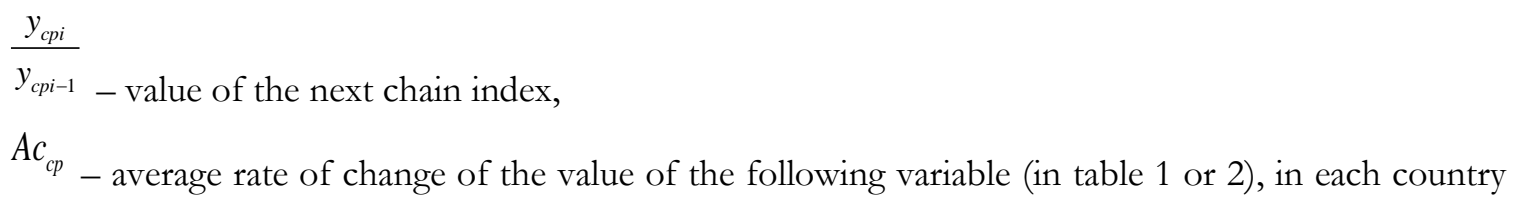
under analysis.

Using equations 2 and 3 the values of variables presented in table 3 , have been obtained and results have been presented in tables 5 and 6 .

Table 3

Variables calculated in the third stage of the research

\begin{tabular}{|l|l|}
\hline Symbol & \multicolumn{1}{c|}{ Description } \\
\hline $\mathrm{Ac}_{\mathrm{C} 1}$ & Average rate of change of the total intramural R\&D expenditure (GERD) of higher education sector. \\
\hline $\mathrm{Ac}_{\mathrm{C} 2}$ & Average rate of change of women being $\mathrm{R}+\mathrm{D}$ personnel and researchers of higher education sector. \\
\hline $\mathrm{Ac}_{\mathrm{C} 3}$ & Average rate of change of men being $\mathrm{R}+\mathrm{D}$ personnel and researchers of higher education sector. \\
\hline $\mathrm{Ac}_{\mathrm{C} 4}$ & Average rate of change of women being inventors of patents of the higher education sector. \\
\hline $\mathrm{Ac}_{\mathrm{C} 5}$ & Average rate of change of men being inventors of patents of the higher education sector. \\
\hline $\mathrm{Ac}_{\mathrm{C} 6}$ & $\begin{array}{l}\text { Average rate of change of the women to men ratio, being } \mathrm{R}+\mathrm{D} \text { personnel and researchers of higher } \\
\text { education sector. }\end{array}$ \\
\hline $\mathrm{Ac}_{\mathrm{C} 7}$ & $\begin{array}{l}\text { Average rate of change of the women to men ratio, being inventors of patents of the higher } \\
\text { education sector. }\end{array}$ \\
\hline
\end{tabular}

Source: author's own work

The results allowed to conduct the comparison, and to phrase conclusions and recommendations.

\section{RESEARCH RESULTS AND DISCUSSION}

\subsection{Identification of the leading countries in terms of creative patent activity}

The first stage of research work was executed for each of the $28 \mathrm{EU}$ member states. It consisted of selecting two groups of leading countries in terms of the number of women and men inventors from 19 EU countries and from 9 transition countries that are currently members of the EU: Bulgaria, Czech Republic, Estonia, Lithuania, Latvia, Poland, Romania, Slovakia and Hungary. The identification of these groups was conducted in two steps. In the first one, the criterion was the share of women, men and women and men inventors in the total number of women, men and women and men in 19 EU countries and 9 transition EU countries. In the second step, the criterion was the share of women, men, and women and men inventors of patents per $1 \mathrm{~m}$ citizens, women, men, and women and men.

In the period under analysis, in all EU member states 58678 women and 733281 men were regarded as inventors of patents. The total number of women and men inventors was 791959 . In table 4 the proportions of women and men as inventors of patents are presented.

Columns 2, 3 and 4 (table 4) present percentage shares of respectively women, men, and women and men in the total number of respectively women, men, and women and men that are inventors of patents, coming from the EU countries in years 1999-2013. Columns 5, 6 and 7 present shares of respectively women, men, and women and men that were inventors of patents in 1999-2013 per $1 \mathrm{~m}$ inhabitants of the EU countries, respectively women, men, and women and men presented. The share of women and men from a given country in the total number of women and men from all EU countries that are inventors of patents is shown in column 4. 
Share of women and men inventors of the patents in 1999-2013

\begin{tabular}{|c|c|c|c|c|c|c|}
\hline Country & $\begin{array}{c}\text { Share of } \\
\text { women } \\
\text { inventors in a } \\
\text { total number } \\
\text { of women } \\
\text { inventors in } \\
\text { the EU in the } \\
\text { whole period } \\
\text { analysed }\end{array}$ & $\begin{array}{c}\text { Share of men } \\
\text { inventors in a } \\
\text { total number } \\
\text { of men } \\
\text { inventors in } \\
\text { the EU in the } \\
\text { whole period } \\
\text { analysed }\end{array}$ & $\begin{array}{c}\text { Share of } \\
\text { inventors in a } \\
\text { total number } \\
\text { of inventors } \\
\text { in the EU in } \\
\text { the whole } \\
\text { period } \\
\text { analysed }\end{array}$ & $\begin{array}{c}\text { Share of } \\
\text { women being } \\
\text { inventors per } \\
1 \text { m female } \\
\text { inhabitants } \\
{[\%]}\end{array}$ & $\begin{array}{c}\text { Share of men } \\
\text { being } \\
\text { inventors per } \\
1 \text { m of male } \\
\text { inhabitants } \\
{[\%]}\end{array}$ & $\begin{array}{c}\text { Share of } \\
\text { women and } \\
\text { men being } \\
\text { inventors per } \\
1 \mathrm{~m} \text { of } \\
\text { inhabitants } \\
{[\%]}\end{array}$ \\
\hline Austria & $1.02 \%$ & $1.67 \%$ & $1.62 \%$ & $3.54 \%$ & $6.66 \%$ & $6.35 \%$ \\
\hline Belgium & $0.49 \%$ & $0.58 \%$ & $0.58 \%$ & $1.35 \%$ & $1.79 \%$ & $1.75 \%$ \\
\hline Bulgaria & $0.08 \%$ & $0.01 \%$ & $0.02 \%$ & $0.29 \%$ & $0.06 \%$ & $0.07 \%$ \\
\hline Croatia & $0.23 \%$ & $0.02 \%$ & $0.04 \%$ & $1.53 \%$ & $0.18 \%$ & $0.29 \%$ \\
\hline Cyprus & $0.00 \%$ & $0.00 \%$ & $0.00 \%$ & $0.06 \%$ & $0.06 \%$ & $0.06 \%$ \\
\hline Czech Republic & $0.25 \%$ & $0.14 \%$ & $0.15 \%$ & $0.70 \%$ & $0.45 \%$ & $0.47 \%$ \\
\hline Denmark & $2.58 \%$ & $1.54 \%$ & $1.61 \%$ & $13.81 \%$ & $9.09 \%$ & $9.54 \%$ \\
\hline Estonia & $0.03 \%$ & $0.02 \%$ & $0.02 \%$ & $0.69 \%$ & $0.38 \%$ & $0.39 \%$ \\
\hline Finland & $2.36 \%$ & $2.02 \%$ & $2.04 \%$ & $12.91 \%$ & $12.45 \%$ & $12.47 \%$ \\
\hline France & $21.49 \%$ & $15.17 \%$ & $15.64 \%$ & $9.73 \%$ & $7.92 \%$ & $7.99 \%$ \\
\hline Germany & $37.16 \%$ & $53.75 \%$ & $52.52 \%$ & $13.03 \%$ & $21.30 \%$ & $20.57 \%$ \\
\hline Greece & $0.04 \%$ & $0.05 \%$ & $0.05 \%$ & $0.12 \%$ & $0.14 \%$ & $0.14 \%$ \\
\hline Hungary & $0.95 \%$ & $0.34 \%$ & $0.38 \%$ & $2.64 \%$ & $1.12 \%$ & $1.22 \%$ \\
\hline Ireland & $0.36 \%$ & $0.27 \%$ & $0.27 \%$ & $2.49 \%$ & $2.03 \%$ & $2.09 \%$ \\
\hline Italy & $9.76 \%$ & $5.08 \%$ & $5.42 \%$ & $4.79 \%$ & $2.88 \%$ & $3.00 \%$ \\
\hline Latvia & $0.03 \%$ & $0.01 \%$ & $0.01 \%$ & $0.38 \%$ & $0.16 \%$ & $0.17 \%$ \\
\hline Lithuania & $0.02 \%$ & $0.01 \%$ & $0.01 \%$ & $0.14 \%$ & $0.07 \%$ & $0.07 \%$ \\
\hline Luxembourg & $0.05 \%$ & $0.09 \%$ & $0.08 \%$ & $2.94 \%$ & $5.83 \%$ & $5.64 \%$ \\
\hline Malta & $0.00 \%$ & $0.00 \%$ & $0.00 \%$ & $0.00 \%$ & $0.03 \%$ & $0.03 \%$ \\
\hline Netherlands & $1.79 \%$ & $2.25 \%$ & $2.21 \%$ & $3.19 \%$ & $4.44 \%$ & $4.37 \%$ \\
\hline Poland & $0.35 \%$ & $0.14 \%$ & $0.16 \%$ & $0.26 \%$ & $0.12 \%$ & $0.13 \%$ \\
\hline Portugal & $0.08 \%$ & $0.04 \%$ & $0.04 \%$ & $0.22 \%$ & $0.13 \%$ & $0.14 \%$ \\
\hline Romania & $0.04 \%$ & $0.01 \%$ & $0.01 \%$ & $0.05 \%$ & $0.02 \%$ & $0.02 \%$ \\
\hline Slovakia & $0.07 \%$ & $0.02 \%$ & $0.02 \%$ & $0.40 \%$ & $0.12 \%$ & $0.14 \%$ \\
\hline Slovenia & $0.19 \%$ & $0.07 \%$ & $0.08 \%$ & $2.67 \%$ & $1.07 \%$ & $1.21 \%$ \\
\hline Spain & $2.18 \%$ & $0.94 \%$ & $1.03 \%$ & $1.44 \%$ & $0.69 \%$ & $0.76 \%$ \\
\hline Sweden & $4.37 \%$ & $4.14 \%$ & $4.16 \%$ & $14.01 \%$ & $14.58 \%$ & $14.67 \%$ \\
\hline United Kingdom & $14.03 \%$ & $11.65 \%$ & $11.82 \%$ & $6.64 \%$ & $6.23 \%$ & $6.25 \%$ \\
\hline Total & $100 \%$ & $100 \%$ & $100 \%$ & $100 \%$ & $100 \%$ & $100 \%$ \\
\hline
\end{tabular}

Source: author's own work based on: EPO patent statistics (2014), available at Thomson Innovation: http://www.thomsoninnov-ation.com/ti/conte-ntsets/patents/, (Accessed: 08.12.15).

The share of inventors (women and men) coming from Germany, France, UK, Italy, Sweden, the Netherlands, Finland, Austria, Denmark and Spain comprise $98.07 \%$ of total inventors from all EU member states in the period under study. The shares of inventors coming from 9 transition states comprise $0.78 \%$ of a total number of inventors. The share of inventors coming from Poland, Hungary and Czech Republic comprise $88.46 \%$ of total inventors (women and men) coming from all post-socialist states under study in the analysed period. The gap between the number of inventors in leading European countries, and new member states characterised by transition economies required the introduction of the division into leading 
EU countries, and leading transition economies, both in terms of the share of innovators. This division is used in the following part of the article.

The presented results from the first step of the identification of the leading groups point at the following countries as leaders from the EU countries in terms of creative activity in patents in years 19992013: Germany, France, UK, Italy, Sweden, the Netherlands, Finland, Austria, Denmark and Spain. Among the 9 transition countries Poland, Hungary and Czech Republic may be considered leaders in term of creative patent activity in $1999-2013$.

The second step of the identification of groups of the leading countries, the criterion of the share of women, men, and women and men inventors of patents per $1 \mathrm{~m}$ inhabitants, women, men, and women and men in analysed period was adopted.

The results presented in the column 7 shows that shares of inventors (women and men) coming from Germany, Sweden, Finland, Denmark, France, UK, Luxemburg, the Netherlands and Italy comprise $90.85 \%$ of total number of inventors (women and men) per $1 \mathrm{~m} \mathrm{EU}$ inhabitants in the analysed period. Shares of 9 transition states comprise $2.69 \%$ of total number of women and men inventors of patents per $1 \mathrm{~m} \mathrm{EU}$ inhabitants. Share of inventors (women and men) coming from Poland, Hungary, Czech Republic, Latvia and Estonia comprise $88.49 \%$ of total number of inventors (women and men) coming from the transition economies in the analysed period.

As a result of the second step of the identification of leading countries in terms of creative activity per $1 \mathrm{~m}$ inhabitants, both women and men, and women and men together, it could be stated that for the EU the leading countries are as follows: Germany, France, UK, Italy, Sweden, the Netherlands, Finland, Austria, Denmark and Luxemburg. While comparing the results of the first and the second steps of the identification, it could be noticed that nine countries are the same. There are, however, differences in both steps - there is Spain identified as a leading country in the first step, and Luxemburg in the second. Taking into consideration the number of inhabitants, Spain makes up more than $22 \%$ of all EU inhabitants, while Luxemburg only $0.5 \%$. Due to this, Spain is more significant state in terms of the number of citizens. Additionally, there were 8146 inventors of patents in Spain, while in Luxemburg only 657 for the whole period under study, which makes Spanish inventors a cohort 12 times bigger. Thus, for further research Spain was chosen for the group of leading EU countries. The first identified group of the leading EU countries in terms of the creative activities consists of: Germany, France, UK, Italy, Sweden, the Netherlands, Finland, Austria, Denmark and Spain. There is quite a different situation in the 9 transition EU states. None of these countries could be considered a leading country in terms of creative activity, therefore none is enlisted in the first group.

In the second step of identification, Latvia and Estonia, along with Czech Republic, Hungary and Poland, were identified. The reason for it is probably the low number of inhabitants, since creative activity in these two countries is one of the lowest among post-socialist EU states. In the analysed period, there were 18 women and 73 men inventors of patents in Latvia, and respectively 20 and 110 in Estonia. Due to this, and taking into consideration main research questions, the second group of the leading countries in terms of creative activity consists only of Czech Republic, Poland and Hungary.

\subsection{The dynamics of changes in women and men being inventors of patents in higher education sectors of the leading EU countries}

Figure 1 presents the results of the second stage of the study for 10 leading European countries, in which average rate of change in the number of women and men being inventors in organizations belonging to the higher education sector in the 1999-2013 has been determined. The highest dynamics of growth of 
the number of women and men creators of patents obtained from EPO by organizations belonging to higher education sector appeared in Denmark, where the numbers for women and men were respectively on average $28.91 \%$ and $21.72 \%$ annually.

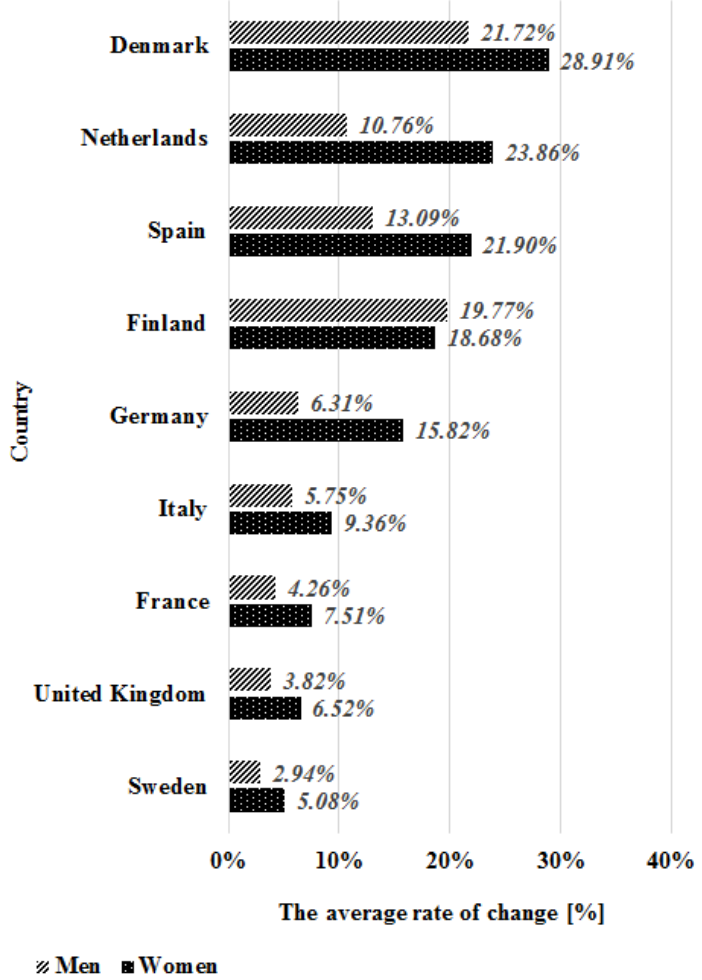

Figure 1. Average rate of changes of women and men being inventors of patents in the higher education sector in the 1999-2013

Source: authors' own work.

Conducted study shows that only in Finland the dynamics of growth of the number of women was lower than the dynamics of the growth of the number of men among creators of parents in the higher education sector. In all other EU leading countries, the dynamics of growth of the number of women is higher than the dynamics of growth of the number of men, who are creators of patents in the higher education sector.

This conclusion is confirmed by the dynamics of changes in the ratio of the number of women to the number of men, who are creators of patents in the higher education sector (table 5 , variable $A_{C}$ ). The highest dynamics of growth of the number of women to the number of men was found in the Netherlands, where the ratio for patent creators in the higher education sector increased annually on average by $11.83 \%$, and the lowest dynamics was found in Sweden $2.08 \%$.

To conclude it may be said that in eight EU leading countries the patent activity of women, represented by the dynamics of changes of the number of patent creators in the higher education sector, is higher than patent activity of men. The countries that constitute the exception from this rule are: Austria, where only four women were patent creators in comparison to $125 \mathrm{men}$ in the whole period studied, and Finland, where there was a decrease of the number of women in comparison to the number of men, who were patent creators in the, annually on average by $0.91 \%$. 


\subsection{The results of the dynamics of changes calculation concerns the higher education sectors of the leading EU countries}

In the third stage of studies the average rate of changes of variables described in table 3 for EU leading countries have been calculated, and they are presented in table 5 .

Table 5

Average rate of change of variables describing patent activity of the leading EU Countries in 1999-2013

\begin{tabular}{|l|c|c|c|c|c|c|c|}
\hline Country $\backslash$ Variable & Acr 1 & Acr 2 & Acr 3 & Acr $_{\text {C }}$ & Acr $_{\text {C5 }}$ & Acr $_{\text {C6 }}$ & Acr 7 \\
\hline Austria & $6.19 \%$ & $7.69 \%$ & $4.20 \%$ & n/a & $22.43 \%$ & $3.35 \%$ & n/a \\
\hline Denmark & $9.92 \%$ & $9.75 \%$ & $5.75 \%$ & $28.91 \%$ & $21.72 \%$ & $3.77 \%$ & $5.91 \%$ \\
\hline Finland & $4.61 \%$ & $4.60 \%$ & $1.77 \%$ & $18.68 \%$ & $19.77 \%$ & $2.77 \%$ & $-0.91 \%$ \\
\hline France & $4.89 \%$ & $1.39 \%$ & $2.05 \%$ & $7.51 \%$ & $4.26 \%$ & $-0.64 \%$ & $3.11 \%$ \\
\hline Germany & $4.30 \%$ & $4.35 \%$ & $2.20 \%$ & $15.82 \%$ & $6.31 \%$ & $2.10 \%$ & $8.95 \%$ \\
\hline Italy & $3.58 \%$ & $3.95 \%$ & $1.39 \%$ & $9.36 \%$ & $5.75 \%$ & $2.52 \%$ & $3.41 \%$ \\
\hline Netherlands & $4.38 \%$ & $2.71 \%$ & $-0.18 \%$ & $23.86 \%$ & $10.76 \%$ & $2.89 \%$ & $11.83 \%$ \\
\hline Spain & $6.53 \%$ & $4.05 \%$ & $1.91 \%$ & $21.90 \%$ & $13.09 \%$ & $2.11 \%$ & $7.79 \%$ \\
\hline Sweden & $5.18 \%$ & $2.27 \%$ & $0.55 \%$ & $5.08 \%$ & $2.94 \%$ & $1.71 \%$ & $2.08 \%$ \\
\hline United Kingdom & $4.20 \%$ & $3.87 \%$ & $2.46 \%$ & $6.52 \%$ & $3.82 \%$ & $1.37 \%$ & $2.60 \%$ \\
\hline
\end{tabular}

Source: author's own work.

The results of study show (table 5) that in Austria there are too few women inventors in organizations belonging to higher education sector. In the whole period studied the number of patents obtained in EPO by organizations belonging to higher education sector equalled 57 . In this number, there were only 4 women identified and 125 men were pointed at as the creators of the patents. Due to this Austria is not considered in case of variables $\mathrm{AC}_{\mathrm{C} 4}$ and $\mathrm{AC}_{\mathrm{C} 7}(\mathrm{n} / \mathrm{a}$ in table 4$)$.

\subsection{The dynamics of changes in women and men being $R \& D$ personnel and researchers in higher education sectors of the leading EU countries}

Results presented in a figure 2 show average rates of changes of R\&D expenditures, women and men being R\&D personnel and researchers, both in higher education sector. The highest dynamics of the growth of $R \& D$ expenditure in higher education sector took place in Denmark, where these expenditures increased by $9.92 \%$ annually. This growth was accompanied by the highest dynamics of growth in the number of women and men in R\&D personnel and researchers in the higher education sector, among all leading EU countries analysed, and the increases were on average respectively $9.75 \%$ and $5.75 \%$ annually.

It is worth noticing that in Austria, Germany and Italy of the growth of the number of women R\&D personnel and researchers in the higher education sector was increasing more rapidly than $\mathrm{R} \& \mathrm{D}$ expenditure in this sector. It is especially interesting due to a fact that in Austria there were 57 patents obtained in EPO by organizations belonging to higher education sector in the whole period studied, for which only 4 women were identified as patent creators, along with 125 men. Such a significant difference in the engagement of women and men in Austria indicates rather small participation of women as creators of patents despite the fact that the dynamics of growth of the number of women as R\&D personnel and researchers in the higher education sector is higher than R\&D expenditures or the number of men. The dynamics of growth of the number of women to the number of men serving as R\&D personnel and researchers in the higher education sector increases most in Austria, when compared to the rest of leading EU countries, on average annually 
by $22.43 \%$. It means that the number of women increased faster than the number of men who serve as R\&D personnel and researchers in the higher education sector in Austria.

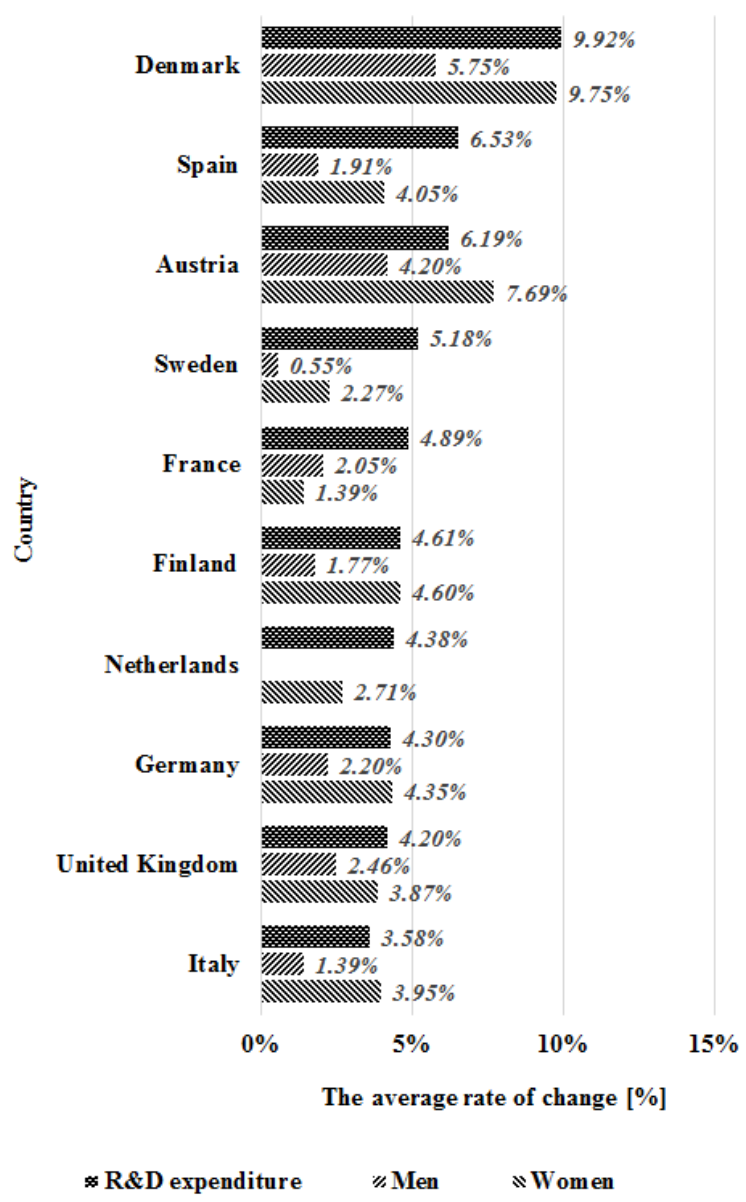

Figure 2. Average rate of changes of $R \& D$ expenditure, women and men being $R \& D$ personnel and researchers in the higher education sector in the 1999-2013

Source: authors' own work.

The dynamics of changes in the ratio of the number of women to the number of men (table 4 variable $\mathrm{AC}_{\mathrm{C} 6}$ ), in the rest of the countries is positive, and that means that the number of women increases faster than the number of men who work as R\&D personnel and researchers in the higher education sector in the whole period studied, with the exception of France, where the number of women in comparison to men decreases annually on average by $0.64 \%$.

The above findings lead to a conclusion that the increase in $\mathrm{R} \& \mathrm{D}$ expenditures in higher education sector triggers the increase in women's and men's patent activities in this sector in a long-run.

\subsection{The dynamics of changes in women and men being inventors of patents in higher education sectors of the leading transition countries}

Stages 2 and 3 have been repeated for leading transition economies. As it was mentioned before, among three leading transitions countries, only Poland can be analyzed with using the dynamic rate of change tool. 
The calculations results are presented in the table 5. The number of female creators of patents in Poland in organizations belonging to the higher education sector increases annually on average by $12.95 \%$, while at the same time the increase in the number of men reached on average $25.29 \%$ annually. This gap is confirmed by the dynamics of changes in the number of women to the number of men that points at the number of female patent creators in the higher education sector decreased in comparison to the number of men annually on average by $9.85 \%$.

In conclusion, in Poland there were significantly lower increase in the number of women, who were creators of patents in comparison to the number of men in organizations belonging to the higher education sector. Among the leading EU countries, the similar situation was noticed only in Austria and Finland. It means that there is a space in Poland to enhance patent activities among women in the higher education sector.

\subsection{The results of the dynamics of changes calculation concerns the higher education sectors of the leading transition countries}

The average rate of changes of variables described in table 3 for the leading transition countries are presented in table 6 .

Table 6

Average rate of change of variables describing patent activity of the leading transition countries in 1999-2013

\begin{tabular}{|l|c|c|c|c|c|c|c|}
\hline Country \Variable & Acr 1 & Acr 2 & Acr 3 & Acr $_{\text {C }}$ & Acr $_{\text {C5 }}$ & Acr 6 & Acr 7 \\
\hline Czech Republic & $18.14 \%$ & $5.57 \%$ & $4.43 \%$ & n/a & n/a & $1.09 \%$ & n/a \\
\hline Hungary & $8.02 \%$ & $0.73 \%$ & $-0.77 \%$ & n/a & n/a & $1.51 \%$ & n/a \\
\hline Poland & $8.99 \%$ & $0.96 \%$ & $0.17 \%$ & $12.95 \%$ & $25.29 \%$ & $0.79 \%$ & $-9.85 \%$ \\
\hline
\end{tabular}

Source: author's own work.

The research revealed that in some countries covered by the analysis in the time series representing the number patents obtained annually by organizations belonging to the higher education sector equals to zero. Such situation concerns the Czech Republic and Hungary. Consequently, the number of women and men being inventors of patents in organizations belonging to the higher education sector cannot be analyzed with dynamic rate of change (marked $\mathrm{n} / \mathrm{a}$ in table 6 ). Such situation may indicate that in some countries patent activity had rather occasional not continuous nature. Despite that the total number of patents obtained in the entire research period allow to point out three leading transition countries, only Poland can be analyzed from the point of view of the dynamics of change in patent activity of women and men in the adopted study period.

\subsection{The dynamics of changes in women and men being $R \& D$ personnel and researchers in higher education sectors of the leading transition countries}

Presented results in figure 3 show that the highest dynamics of growth of R\&D expenditure in the higher education sector appeared in Czech Republic, where these expenditures were growing annually on average by $18.14 \%$. Such dynamics is approximately twice as high as the dynamics of growth of R\&D expenditures in Denmark (figure 2, 9.92\%), which is one of the leading EU countries in terms of the patent activity. This growth was accompanied by the highest dynamics of growth in the number of women and men serving as R\&D personnel and researchers in the higher education sector among transition economies, 
where these numbers increased annually on average by $5.55 \%$ and $4.43 \%$. In Denmark, where the dynamics of growth of $\mathrm{R} \& \mathrm{D}$ expenditures was twice as low, the dynamics of growth of the number of women was almost twice as high as in Czech Republic (9.75\% in Denmark and 5.57\% in Czech Republic). At the same time, the dynamics of change in the number of men in Denmark was a little bit higher than in Czech Republic. (5.75\%, and $4.43 \%$ respectively).

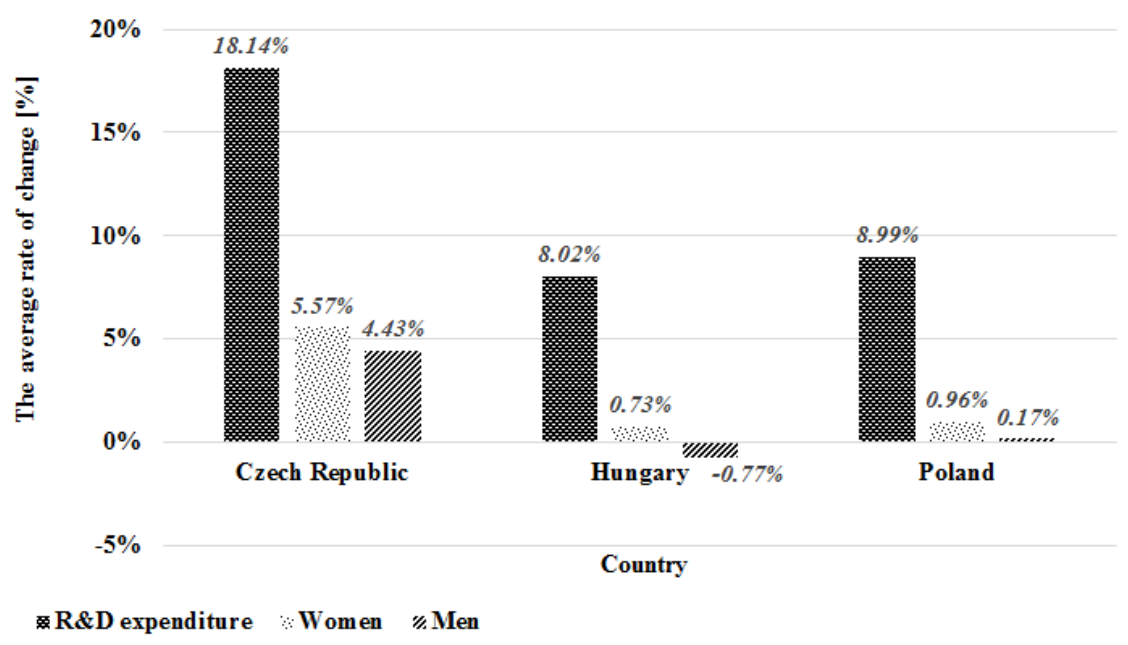

Figure 3. Average rate of changes of $R \& D$ expenditure, women and men being $R \& D$ personnel and researchers in the higher education sector in the 1999-2013 in the transition countries Source: author's own work.

Faster pace of growth in the number of women in comparison to the number of men serving as R\&D personnel and researchers in the higher education sector was noticed in all three transition economies (table 6 , variable $\mathrm{AC}_{\mathrm{C} 6}$ ). The fastest pace appeared in Hungary $1.51 \%$, what can be linked to the fact that only in this country there was a decrease in the average number of men serving as $\mathrm{R} \& \mathrm{D}$ personnel and researchers in the higher education sector annually on average by $0.77 \%$. In Poland the increase in the number of women to the number of men, who serve as R\&D personnel and researchers in the higher education sector equalled $0.79 \%$. At the same time, the level of dynamics of growth in R\&D expenditures in the higher education sector in Hungary and Poland was close to that of Denmark, but it was accompanied by very small increase in the number of women and men serving as R\&D personnel and researchers in the higher education sector in Poland and women in Hungary.

Based on conducted study it may be concluded that the dynamics of growth in R\&D expenditures in transition economics is not directly linked to the growth in the number of women and men serving as R\&D personnel and researchers in the higher education sector, at least not in the same degree as in EU leading countries. This difference suggests different way of allocation of resources devoted to R\&D in the higher education sector in these countries. There is inefficiently used innovative potential that should be of interest of groups responsible for allocation of resources devoted to $\mathrm{R} \& \mathrm{D}$ in this sector, and for shaping conditions promoting patent activities among women in this sector. However more detailed analysis and assessment of structure of patents obtained by organizations belonging to the higher education sector in these countries is necessary to point at the differences in the allocation of resources devoted for particular areas of knowledge. 


\section{CONCLUSIONS}

In the presented article the dynamics of changes in gender structure of patent inventors and $R \& D$ personnel, along with the dynamics of change in the $\mathrm{R} \& \mathrm{D}$ expenditures, all in higher education sector, have been analysed. The findings lead to a conclusion that the increase in $\mathrm{R} \& \mathrm{D}$ expenditures in higher education sector triggers the increase in women's and men's patent activities in this sector in a long-run in EU leading countries. In eight EU leading countries the patent activity of women, represented by the dynamics of changes of the number of patent creators in the higher education sector, is higher than patent activity of men. The countries that constitute the exception from this rule are: Austria, where only four women were patent creators in comparison to $125 \mathrm{men}$ in the whole period studied, and Finland, where there was a decrease of the number of women in comparison to the number of men, who were patent creators in the, annually on average by $0.91 \%$. At the same time, the dynamics of growth in R\&D expenditures in transition economics is not directly linked to the growth in the number of women and men serving as R\&D personnel and researchers in the higher education sector, at least not in the same degree as in EU leading countries. There is inefficiently used innovative potential in transition economies that should be of interest of groups responsible for allocation of resources devoted to R\&D in this sector, and for shaping conditions promoting patent activities among women in this sector.

The obtained results could be also compared to the results regarding the business sector. The comparison between the two shows similar trends, increases in R\&D expenditures both in business and higher education sectors triggered an increase in the number of inventions introduced by female R\&D personnel in EU leading countries. In leading transition countries, there has been an increase in R\&D expenditures, which however has not produced same results in terms of the number of female inventors. The outcomes of the study highlight a gender problem that needs to be further researched. There are factors that influence gender relations in analysed countries, such as political and cultural, which have not been addressed by the presented study. The following research should take all the institutional factors into account, while trying to answer the questions regarding the gender gap in innovations.

\section{REFERENCES}

Abels, G. (2012). Research by, for and about Women: Gendering Science and Research Policy. In G. Abels and J. M. Mushaben, (Eds.), Gendering European Union. New Approaches to Old Democratic Deficits (pp. 187-207). Basingstoke: Palgrave Macmillan.

Alsos, G.A., Ljunggren, E., \& Hytti, U. (2013). Gender and innovation: state of the art and a research agenda. International Journal of Gender and Entrepreneurship, 5(3), 236-256.

Carrasco, I. (2014). Gender gap in innovation: an institutionalist explanation. Management Decision, 52(2), 410-424.

Cohen W.M., \& Merrill S.A. (2003). Patents in the Knowledge-Based Economy. The National Academies Press, Washington.

Cohen, W. M., Nelson, R. R., \& Walsh, J. P. (2002). Links and impacts: the influence of public research on industrial $\mathrm{R} \& \mathrm{D}$. Management science, $48(1), 1-23$.

European Commission. (2001). Regular Reports from the Commission on Hungary's Progress towards Accession. Retrieved 2014 from http://ec.europa.eu/enlargement/archives/key documents/reports $2001 \mathrm{en.htm}$.

Fogelberg Eriksson, A. (2014). A gender perspective as trigger and facilitator of innovation. International Journal of Gender and Entrepreneurship, 6(2), 163-180.

Foss, L., Woll, K., \& Moilanen, M. (2013). Creativity and implementations of new ideas: do organisational structure, work environment and gender matter?. International Journal of Gender and Entrepreneurship, 5(3), 298-322.

Freedman, D., Pisani, R., \& Purves, R. (2007). Statistics. W. W. Norton \& Company, New York.

Frietsch, R., Haller, I., Funken-Vrohlings, M., \& Grupp, H. (2009). Gender-specific patterns in patenting and publishing. Research Policy, 38, 590-599.

Griliches, Z. (1990). Patent Statistics as Economic Indicators: A Survey. Journal of Economic Literature, 28, 1661-1707. 
Guellec, D., \& de La Potterie, B. V. P. (2007). The economics of the European patent system: IP policy for innovation and competition. Oxford University Press on Demand.

Guellec, D., \& Pottelsberghe van, B. (2000). Applications, Grants and the Value of Patents. Economic Letters, 69(1), 109114.

Guellec, D., \& Pottelsberghe van, B. (2001). The Internationalisation of Technology Analysed with Patent Data. Research Policy, 30(8), 1256-1266.

Hirschey, M., \& Richardson, V. J. (2004). Are scientific indicators of patent quality useful to investors?. Journal of Empirical Finance, 11(1), 91-107.

Hughes-Hallett, D., Lock, P. F., Gleason, A. M., Flath, D. E., Lovelock, D., Quinney, D., Connally, E., Lonzano, G. I., Rhea, K. R., Kalaycý, S., McCallum, W. G., Speigler, A. H., Lahme, B., \& Osgood, B. G. (2014). Applied Calculus. Willey, New York.

Hunt, J., Garant, J. P., Herman, H., \& Munroe, D. J. (2013). Why are women underrepresented amongst patentees?. Research Policy, 42(4), 831-843.

Jaffe, A. B., Trajtenberg, M., \& Henderson, R. (1993). Geographic localization of knowledge spillovers as evidenced by patent citations. the Quarterly journal of Economics, 108(3), 577-598.

Jönsson, P., \& Carlsson, I. (2000). Androgyny and creativity: A study of the relationship between a balanced sex-role and creative functioning. Scandinavian Journal of Psychology, 41(4), 269-274.

Okoń-Horodyńska, E., Zachorowska-Mazurkiewicz, A., Wisła, R., \& Sierotowicz, T. (2015). Gender in the creation of intellectual property of the selected European union countries. Economics \& Sociology, 8(2), 11-25.

Østergaard, C. R., Timmermans, B., \& Kristinsson, K. (2011). Does a different view create something new? The effect of employee diversity on innovation. Research Policy, 40(3), 500-509.

Pavitt, K., Robson, M., \& Townsend, J. (1989). Technological accumulation, diversification and organisation in UK companies, 1945-1983. Management science, 35(1), 81-99.

Schmoch, U. (1997). Indicators and the relations between science and technology. Scientometrics, 38(1), 103-116.

Schmoch, U. (2008). Concept of a technology classification for country comparisons. Final report to the world intellectual property organisation (wipo), WIPO.

Schumpeter, J.A. (1934). The theory of economic development. Oxford University Press, New York.

Sugimoto, C. R., Lariviere, V., Ni, C., Gingras, Y., \& Cronin, B. (2013). Global gender disparities in science. Nature, 504(7479), 211-213.

Whittington, K. B., \& Smith-Doerr, L. (2005). Gender and commercial science: Women's patenting in the life sciences. The Journal of Technology Transfer, 30(4), 355-370.

Zachorowska-Mazurkiewicz, A., \& Sierotowicz, T. (2016). Women, men and creativity in business sector-comparative studies of leading EU and ECE countries. Journal of Research in Business, Economics and Management, 5(3), 609-624. 